\title{
PENGARUH BUDAYA MAKAN DENGAN TANGAN TERHADAP PENYEBARAN COVID-19 DI KOTA BANDUNG
}

\author{
Gregorius Kevin Setiawan, Ayodya Kuncoroadi Yudhitama Wardana, Aileen Devita \\ Adjani, \& Zahra Salsabila \\ Institut Teknologi Bandung. \\ email: gregorius.kevin17@gmail.com
}

\begin{abstract}
Abstrak
Pandemi Covid-19 yang terus berlanjut menyebabkan krisis kesehatan pada banyak negara, termasuk Indonesia. Hal ini disebabkan oleh kemampuan virus yang menyebar dengan cepat. Kota Bandung, sebagai salah satu kota dengan jumlah penduduk yang padat juga terkena dampak dari pandemi ini. Untuk mengatasi pandemi, pemerintah Indonesia melakukan upaya seperti penerapan physical distancing, di mana pada aturan tersebut masyarakat diimbau untuk mencuci tangan dengan benar, menjauhi kerumunan, selalu menggunakan masker, dsb. Pandemi dan rasa khawatir masyarakat berpengaruh pada salah satu budaya bangsa Indonesia, yakni budaya makan dengan tangan. Budaya ini sudah dilakukan sejak dahulu kala dan dilakukan secara turun-temurun oleh masyarakat Indonesia. Pada penelitian ini, akan ditentukan pengaruh budaya makan dengan tangan terhadap penyebaran Covid-19 di Kota Bandung, beserta faktor lain yang memungkinkan terjadinya penyebaran Covid-19 tersebut. Penelitian ini dilakukan secara kualitatif dengan cara studi literatur, pencarian data dari sampel melalui pengisian kuesioner, dan analisis data secara korelasi parsial. Dari segi kuantitatif, analisis data dilakukan dengan menaksir data kebiasaan penduduk Kota Bandung dari data sampel melalui pencarian selang kepercayaan dengan taraf signifikansi 95\%. Berdasarkan data dari 102 responden, didapatkan bahwa 15.7\% responden pernah terjangkit Covid-19, 98\% persen responden selalu menggunakan masker saat keluar rumah, dan 42.2\% responden pernah berkerumun saat pandemi. Dengan penaksiran selang kepercayaan, didapatkan penduduk Kota Bandung yang pernah ataupun yang belum pernah terjangkit Covid-19 memiliki frekuensi makan dengan tangan "kadang-kadang". Penduduk Kota Bandung yang pernah terjangkit Covid-19 mencuci tangan dengan benar sebelum makan, baik dengan tangan maupun peralatan makan, dengan frekuensi "kadang-kadang" sampai "sangat sering", sedangkan yang tidak pernah terjangkit Covid-19 mencuci tangan dengan benar sebelum makan dengan frekuensi "sangat sering". Dari hal tersebut, dapat disimpulkan bahwa budaya makan dengan tangan tidak berpengaruh terhadap penyebaran Covid-19 di Kota Bandung. Hal yang mempengaruhi penyebaran Covid-19 adalah kebiasaan mencuci tangan, menggunakan masker, dan stay at home.
\end{abstract}

Kata Kunci: covid-19; budaya; makan dengan tangan

\begin{abstract}
The ongoing Covid-19 pandemic has caused a health crisis in many countries, including Indonesia. This is due to the ability of the virus to spread quickly. The city of Bandung, as one of the cities with a dense population, has also been affected by this pandemic. To overcome the pandemic, the Indonesian government has made efforts such as implementing physical distancing, in which the public is advised to wash their hands properly, stay away from crowds, always wear masks, etc. The pandemic and people's worries have an effect on one of the Indonesian cultures, namely the culture of eating with hands. This culture has been carried out since a very long time ago and is carried out from generation to generation by the people of Indonesia. In this study, it will determine the influence of the culture of eating with hands on the spread of Covid-19 in Bandung City, along with other factors that allow the spread of Covid-19. This research was conducted qualitatively by means of a literature study, searching for data from samples through filling out questionnaires, and analyzing data by partial correlation. From a quantitative point of view, data analysis was carried out by estimating the habit data of the population of Bandung from the sample data by searching for a confidence interval with a significance level of 95\%. Based on data from 102 respondents, it was found that 15.7\% of respondents has been infected by Covid-19, 98\% percent of respondents always used masks when leaving the house, and $42.2 \%$ of respondents had gone out in crowds during a pandemic. By using a confidence interval estimation, it was found that residents of Bandung City
\end{abstract}


who have or have never been infected with Covid-19 have a frequency of eating with their hands "sometimes". Residents of Bandung City who have been infected with Covid-19 wash their hands properly before eating, both with hands and cutlery, with a frequency of "sometimes" to "very often", while those who have never been infected with Covid-19 wash their hands properly before eating. with a "very frequent" frequency. From this, it can be concluded that the culture of eating with hands has no effect on the spread of Covid-19 in the city of Bandung. Things that affect the spread of Covid-19 are the habits of washing hands, wearing masks, and staying at home.

Key Words: covid-19, culture, eat with hands

\section{PENDAHULUAN}

Saat ini dunia sedang dilanda krisis kesehatan akibat pandemi Covid-19 (coronavirus disease) atau lebih dikenal dengan virus corona. Virus ini merupakan virus corona jenis baru dari SARS-CoV-2 yang ditemukan di Wuhan, ibukota provinsi Hubei China pada akhir tahun 2019 dan telah diumumkan oleh WHO sebagai pandemi pada 11 Maret 2020 (Suryani et al., 2020). Saat terdapat kasus infeksi sebanyak 2.033.807 di dunia, sebanyak 129.876 di antaranya meninggal dunia (Armiani et al., 2020) (Rachman et al., 2021).

Sementara itu, WHO (Nurgiansah, 2020c) menyatakan bahwa penyebaran virus corona sangat berkembang dengan pesat. Hal tersebut dibuktikan dengan penyebaran virus yang merambah hampir ke seluruh dunia, termasuk Indonesia. Di Indonesia, Covid-19 terasa begitu lekat. Awal mula kasus di Indonesia, terjadi pada bulan Maret 2020 yang kemudian tumbuh serta menyebar ke daerah daerah yang ada di Indonesia. Setiap harinya kasus terkonfirmasi positif terinfeksi virus corona terus bertambah. Begitu halnya dengan pasien yang meninggal dunia akibat infeksi beserta komplikasi penyakit berat sehingga persentase bertahan menjadi lebih rendah.

Adapun total kasus di Indonesia mencapai

392.934 pasien terinfeksi, 13.411 pasien meninggal, dan 317.672 pasien yang sembuh (Yanuarita \& Haryati, 2021) (Nurgiansah, 2021c). Sementara itu, terhitung Bandung yang terdampak coronavirus dimana data menunjukan 4,25 juta kasus dan 144 ribu meninggal dunia.
Fenomena ini membawa petaka bagi kehidupan sosial dan budaya masyarakat khususnya di Kota Bandung.

Terlebih sejak diberlakukannya social distancing yang kemudian diubah penamaannya menjadi physical distancing. Pada pemberlakuannya, masyarakat diimbau agar menjauhi kontak fisik antara satu orang dengan lainnya, selalu berdiam dirumah, menghindari kerumunan, selalu mencuci tangan dengan benar, hingga selalu memakai masker (Aulia, 2021) (Nurgiansah, 2021a).

Budaya mencuci tangan dengan benar tidak lagi berlaku hanya ketika pada saat mau makan menggunakan tangan, namun sejak adanya pandemi ini, setiap orang yang berkunjung ke suatu tempat, atau pun setelah pulang dari luar rumah, setiap individu mayoritasnya sudah terbiasa untuk mencuci tangan dengan benar.

Indonesia memiliki banyak kekayaan adat serta budaya yang beragam, mulai dari Sabang sampai Merauke, yang tersebar beranekaragam dan budayanya yang telah diwariskan secara turun temurun (Gunawan et al., 2020) (Nurgiansah, 2020b). Yang salah satu menjadi kebiasaan adalah budaya makan menggunakan tangan. Rekomendasi WHO dalam menghadapi wabah Covid-19 adalah dengan melakukan proteksi dasar dengan melakukan cuci tangan secara rutin dengan menggunakan alkohol atau sabun dan air (Wasaraka, 2021)(Nurgiansah, 2021d).

Air saja tidak cukup untuk menghilangkan coronavirus sehingga harus menggunakan sabun (Riedel et al., 2019) (Nurgiansah, 2021e). Kekhawatiran 
terhadap infeksi corona akan berdampak pada perubahan kebiasaan makan dan kebiasaan cuci tangan dengan benar masyarakat demi terhindar dari infeksi virus corona. Tujuan penelitian ini adalah untuk mengetahui pengaruh budaya makan dengan tangan terhadap penyebaran Covid19 di Kota Bandung, beserta faktor lain yang memungkinkan terjadinya penyebaran Covid-19 tersebut. Penelitian ini juga dilakukan untuk mengetahui kebiasaan makan dan kebiasaan mencuci tangan dengan benar penduduk Kota Bandung selama pandemi Covid-19.

\section{METODE PENELITIAN}

Penelitian ini merupakan penelitian kualitatif dan kuantitatif dengan tahapan penelitian berupa tahap studi literatur, tahap pencarian data, tahap analisis data, dan tahap penulisan laporan. Penelitian ini dilakukan secara daring dengan tujuan untuk menentukan pengaruh budaya makan dengan tangan terhadap penyebaran Covid-19 di Kota Bandung. Studi literatur dilakukan dengan mencari sumber-sumber literasi mengenai budaya makan dengan tangan dan berbagai faktor penting dalam proses penyebaran Covid-19 (Nurgiansah, 2020a).

Sumber literasi didapatkan dari artikel dalam jurnal yang ada di internet (Nurgiansah, 2021b). Setelah melakukan studi literatur, kami mencari data untuk membuktikan apakah budaya makan dengan tangan memiliki korelasi terhadap penyebaran Covid-19 di Kota Bandung. Data ini kami kumpulkan dengan menggunakan formulir online yang sebagian besar respondennya adalah mahasiswa dari daerah Bandung. Data yang didapatkan berupa data kualitatif mengenai pengaruh budaya makan dengan tangan dengan penyebaran covid-19 dan data kuantitatif perbandingan jumlah responden yang pernah terjangkit covid-19 dengan berbagai kebiasaan/budaya yang biasa dilakukan yang salah satunya adalah budaya makan dengan tangan.

Data yang telah dikumpulkan kemudian kami olah. Pengolahan data dilakukan dengan menggunakan metode korelasi parsial dan pencarian selang kepercayaan 95\% untuk penaksiran pada sampel populasi responden. Pada metode korelasi parsial ini, variabel terikat yang digunakan adalah variabel jumlah responden yang terpapar dengan penyakit, dan variabel bebas berupa budaya makan dengan tangan, budaya mencuci tangan dengan benar, budaya menggunakan masker, dan budaya berkerumun.

Kemudian penaksiran dengan selang kepercayaan 95\% digunakan untuk memvalidasi bahwa sampel yang didapatkan dari responden memiliki nilai yang tidak berbeda signifikan dari data asli pada populasi. Hasil pengolahan data kemudian diinterpretasikan menjadi kalimat dan menjadi basis data dari pembuktian keterkaitan dari budaya makan dengan tangan dan penyebaran Covid-19 khususnya di Kota Bandung. Interpretasi dari pengolahan data ini kemudian dibuat dalam sebuah rangkuman untuk menjawab rumusan permasalahan yang kemudian disusun sebagai laporan penelitian.

\section{HASIL PENELITIAN DAN PEMBAHASAN Hasil Penelitian}

Menurut WHO (2020) (Nurgiansah, 2021f), penyebaran SARS-CoV-2 dapat terjadi melalui kontak, droplet, airborne, fomit, darah, ibu ke anak, binatang ke manusia, dan melalui oral. Covid-19 dapat menyebar juga jika seseorang melakukan kontak dengan objek yang terkontaminasi oleh virus SARS-CoV-2, kemudian bagian tubuh melakukan kontak tersebut menyentuh membran mukus (seperti pada mata, hidung, dan mulut) secara langsung (Lotfi et al., 2020). Hal ini berarti, kontak tangan yang terkontaminasi dengan mulut dapat menjadi faktor pemicu penyebaran Covid-19. 
Penyebaran Covid-19 dapat dicegah dengan dengan menggunakan alat protektif seperti sarung tangan, face shield, dan sekurang-kurangnya masker. Selain itu, kebersihan tangan juga perlu dijaga dengan menggunakan disinfektan berbahan dasar alkohol dan juga mencuci tangan dengan sabun (Pradhan et al., 2020). Pencegahan Covid-19 lainnya adalah dengan menjauhkan diri dari kerumunan orang, menjaga tiga sampai empat langkah dari orang lain, menutup mulut dan hidung dengan tisu ketika batuk atau bersin (atau menggunakan bagian dalam siku tangan, dan tidak memegang muka dengan tangan yang kotor (Lotfi et al., 2020).

Cara mencuci tangan yang benar adalah dengan melepaskan segala aksesoris tangan dulu sebelum mencuci tangan, membasahkan tangan dengan air mengalir, menambahkan sabun pada tangan dan menggosok tangan (bagian telapak tangan, punggung tangan, pergelangan, antara jari, pinggir kuku, dan ujung kuku) selama 20 detik, bilas dengan air mengalir, mengeringkan tangan mulai dari pergelangan dengan tisu, dan mematikan keran menggunakan tisu yang sama (GÜNER et al., 2020).

\section{Pembahasan}

Pada penelitian ini, penyebaran kuesioner (google form) dilakukan kepada penduduk Kota Bandung dengan mayoritas responden berupa mahasiswa dan lansia. Pada penelitian ini, diambil juga data yang berkaitan dengan ketaatan seseorang pada protokol kesehatan selama pandemi untuk menentukan faktor lain yang memungkinkan seseorang terjangkit Covid19 selain faktor akibat makan menggunakan tangan. Berdasarkan hasil pengisian kuesioner oleh 102 responden, didapatkan data sebagai berikut:

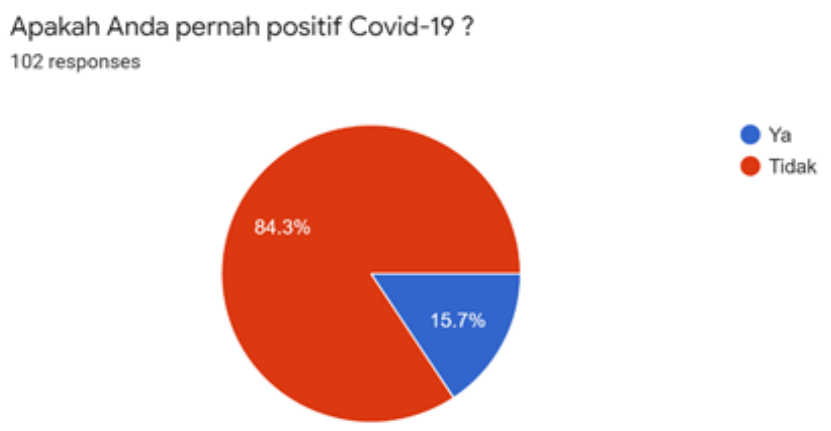

Grafik 1. Persentase responden yang pernah terjangkit Covid-19

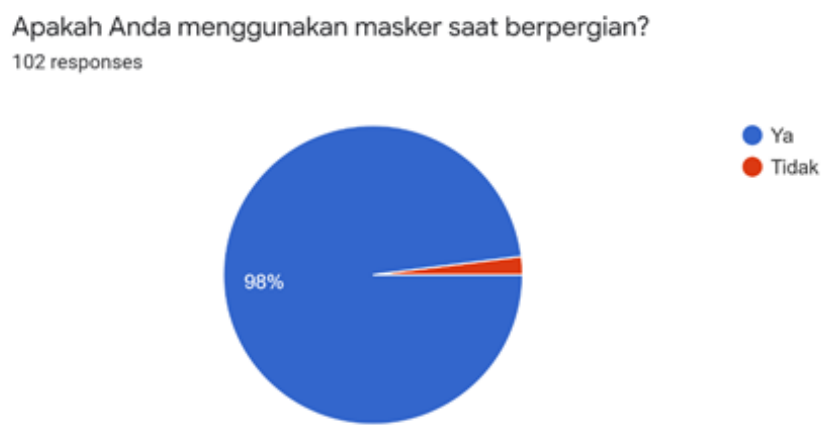

Grafik 2. Persentase responden yang menggunakan masker saat berpergian 
Apakah Anda pernah berkerumun di luar rumah di masa pandemi? 102 responses

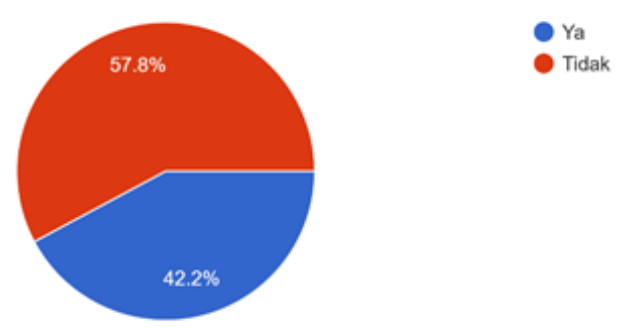

Grafik 3. Persentase responden yang pernah berkerumun di luar rumah pada saat pandemi Covid-19

Diberikan juga pertanyaan dengan pencarian selang kepercayaan 95\% agar jawaban berskala 1, 2, 3, dan 4 yang data sampel dapat mewakili data populasi. menyatakan secara urut: tidak pernah, Berikut adalah data yang didapatkan dari jarang, sering, dan selalu terhadap masing102 responden yang sama: masing pertanyaan. Setelah itu, dilakukan

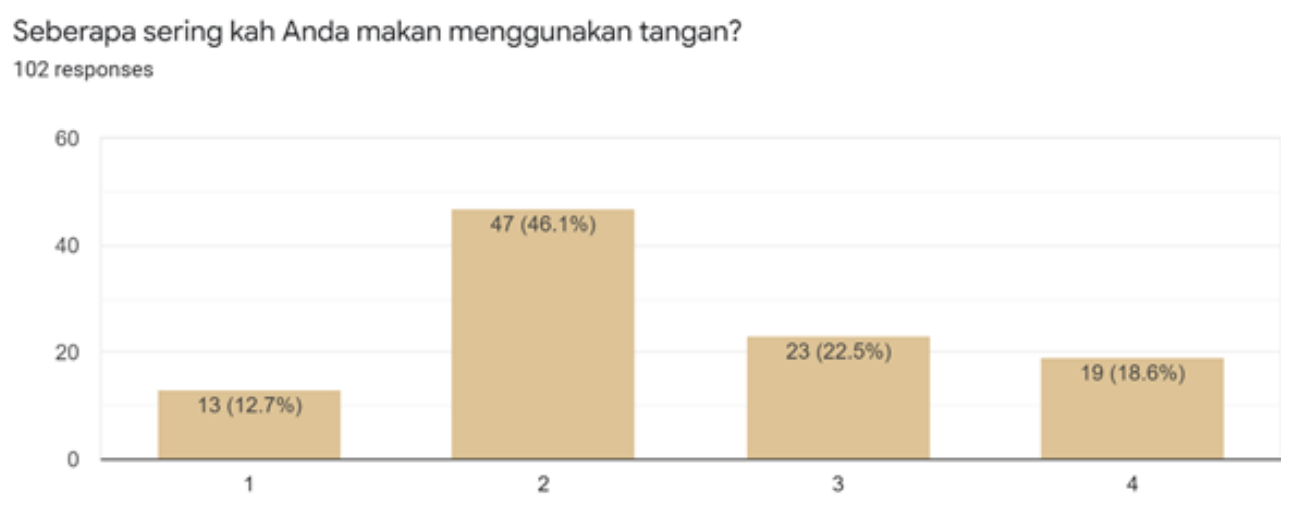

Grafik 4. Tingkat keseringan makan dengan tangan pada penduduk Kota Bandung

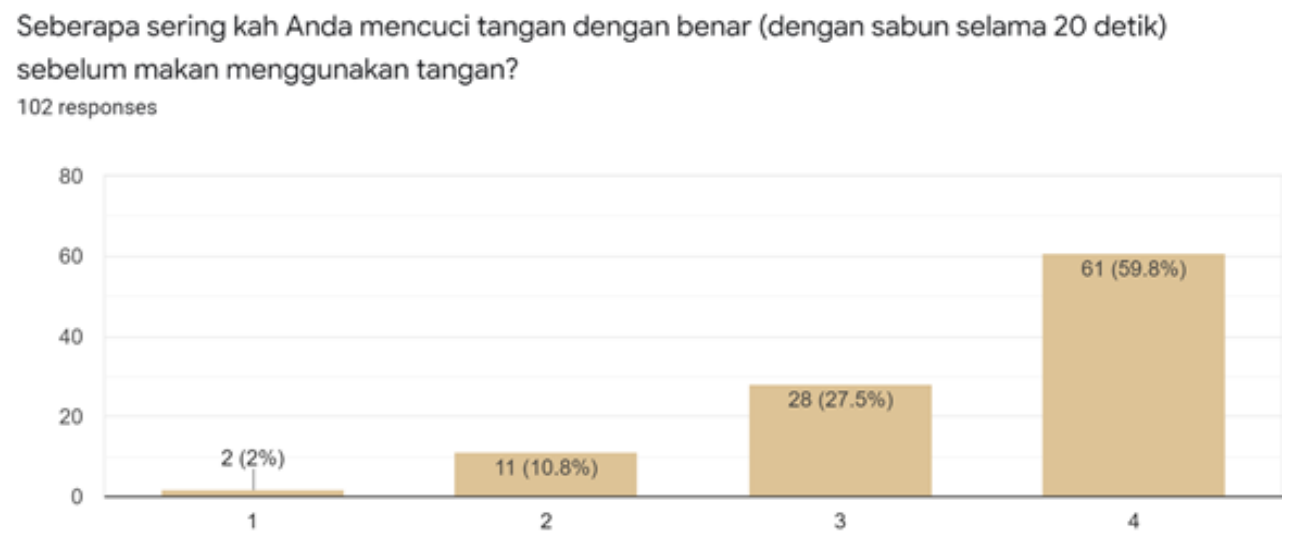

Grafik 5. Tingkat keseringan mencuci tangan dengan benar sebelum makan pada penduduk Kota Bandung 


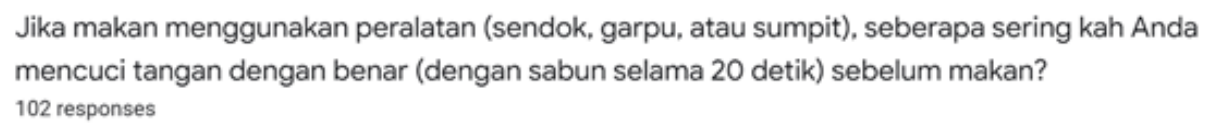
102 responses

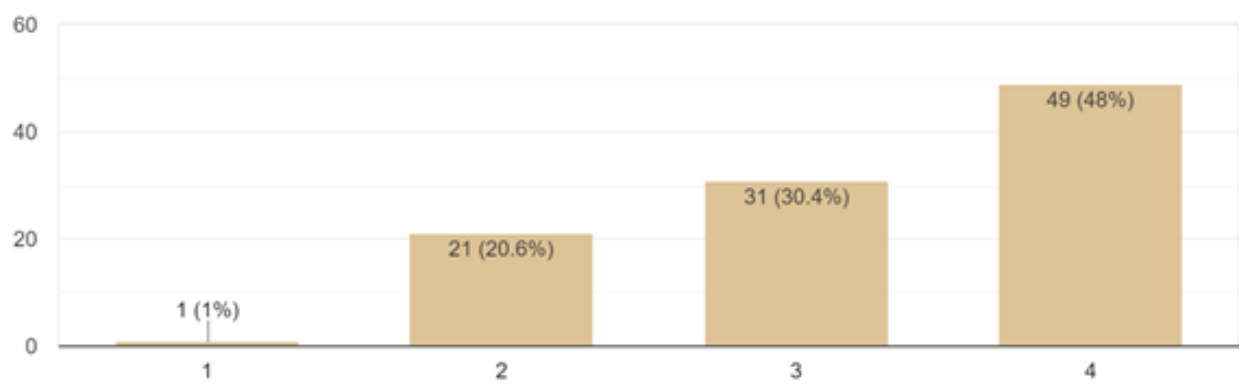

Grafik 6. Tingkat keseringan mencuci tangan dengan benar sebelum makan menggunakan peralatan pada penduduk Kota Bandung

Tabel 1. Selang Kepercayaan 95\% dari Pertanyaan pada (Grafik 4, 5, dan 6).

\begin{tabular}{|c|c|}
\hline Data & Selang Kepercayaan \\
\hline Tingkat keseringan makan dengan tangan pada penduduk Kota Bandung & $\begin{array}{c}2.285781<\mu< \\
2.655396\end{array}$ \\
\hline Tingkat keseringan mencuci tangan dengan benar sebelum makan pada & $3.300533<\mu<$ \\
penduduk Kota Bandung & 3.601428 \\
\hline pingkat keseringan mencuci tangan dengan benar sebelum makan menggunakan & $3.094480<\mu<$ \\
& 3.415324 \\
\hline
\end{tabular}

Tabel 2. Selang Kepercayaan 95\% dari Pertanyaan pada (Grafik 4, 5, dan 6) pada Responden yang Pernah Terjangkit Covid-19.

\begin{tabular}{|l|l|}
\hline Data & Selang Kepercayaan \\
\hline Tingkat keseringan makan dengan tangan pada penduduk Kota Bandung & $2.174875<\mu<$ \\
& $<.950125$ \\
\hline $\begin{array}{l}\text { Tingkat keseringan mencuci tangan dengan benar sebelum makan pada penduduk } \\
\text { Kota Bandung }\end{array}$ & $3.702283<4<$ \\
\hline
\end{tabular}




\begin{tabular}{|l|l|l|}
\hline $\begin{array}{l}\text { Tingkat keseringan mencuci tangan dengan benar sebelum makan menggunakan } \\
\text { peralatan pada penduduk Kota Bandung }\end{array}$ & \\
& \\
\hline
\end{tabular}

Tabel 3. Selang Kepercayaan 95\% dari Pertanyaan pada (Grafik 4, 5, dan 6) pada Responden yang Tidak Pernah Terjangkit Covid-19.

\begin{tabular}{|l|l|}
\hline Data & Selang Kepercayaan \\
\hline Tingkat keseringan makan dengan tangan pada penduduk Kota Bandung & $2.243788<\mu<$ \\
& $<.663189$ \\
\hline $\begin{array}{l}\text { Tingkat keseringan mencuci tangan dengan benar sebelum makan pada penduduk } \\
\text { Kota Bandung }\end{array}$ & $3.343136<4<$ \\
& \\
\hline $\begin{array}{l}\text { Tingkat keseringan mencuci tangan dengan benar sebelum makan menggunakan } \\
\text { peralatan pada penduduk Kota Bandung }\end{array}$ & $3.137659<4<$ \\
\hline
\end{tabular}

Keterangan: $\mu$ menyatakan selang nilai rata-rata yang dipilih dalam populasi penduduk Kota Bandung dari pilihan 1 (tidak pernah), 2 (jarang), 3 (sering), dan 4 (selalu) pada kuesioner.

Diasumsikan selang nilai $1<\mu<2$ menandakan sangat jarang, $2<\mu<3$ menandakan kadang-kadang, dan $3<\mu<4$ menandakan sangat sering (dengan semakin tinggi nilai selang $\mu$, semakin tinggi tingkat keseringannya).

Berdasarkan data pada (Tabel 1), dapat diidentifikasi bahwa penduduk kota bandung kadang-kadang makan dengan tangan dan sangat sering mencuci tangan dengan benar sebelum makan dengan tangan atau makan dengan peralatan makan. Hal ini menunjukkan penduduk Kota Bandung menjaga kebersihan dengan baik, terutama saat sebelum makan.

Pada (Tabel 2 dan 3) teridentifikasi bahwa penduduk Kota Bandung yang pernah ataupun yang belum pernah terjangkit Covid-19 memiliki frekuensi makan dengan tangan "kadang-kadang". Hal ini menandakan budaya makan dengan tangan tidak berpengaruh terhadap penyebaran Covid-19. Dengan kata lain terdapat faktor-faktor lain yang dapat menyebabkan penyebaran Covid-19.

Pada (Tabel 2 dan 3), dapat diidentifikasi bahwa penduduk Kota Bandung yang pernah terjangkit Covid-19 mencuci tangan dengan benar sebelum makan, baik dengan tangan maupun peralatan makan, dengan frekuensi "kadang-kadang" sampai "sangat sering". Sedangkan penduduk Kota Bandung yang tidak pernah terjangkit Covid-19 mencuci tangan dengan benar sebelum makan, baik dengan tangan maupun peralatan makan, dengan frekuensi "sangat sering". Dari fakta tersebut, dapat diidentifikasi bahwa penduduk Kota Bandung yang pernah terjangkit Covid-19 memiliki frekuensi yang lebih rendah dalam hal mencuci tangan dengan benar sebelum makan.

Hal ini menunjukkan bukan budaya makan dengan tangan lah yang menjadi 
salah satu faktor penyebaran Covid-19, melainkan kebiasaan menjaga kebersihan dari masing-masing individu.

Contoh perbedaan kebiasaan lain yang dapat diambil dari responden yang pernah dan tidak pernah terjangkit Covid19 adalah kebiasaan memakai masker saat keluar rumah dan kebiasaan berkerumun di saat pandemi. Berdasarkan data setiap responden, didapatkan 1 dari 16 responden yang pernah terjangkit Covid-19 tidak menggunakan masker saat bepergian keluar rumah, sedangkan 1 dari 86 responden yang tidak pernah terjangkit Covid-19 tidak menggunakan masker saat bepergian keluar rumah.

Didapatkan juga data 8 dari 16 responden yang pernah terjangkit Covid-19 pernah berkerumun di luar rumah, sedangkan 35 dari 86 responden yang tidak pernah terjangkit Covid-19 pernah berkerumun di luar rumah selama masa pandemi Covid-19. Hal ini menunjukkan penduduk yang pernah terjangkit Covid-19 lebih sering keluar rumah tanpa menggunakan masker dan lebih sering berkerumun saat pandemi. Hal ini juga merupakan faktor lain penyebab penyebaran Covid-19 di Kota Bandung.

\section{KESIMPULAN}

Berdasarkan hasil analisa, dapat disimpulkan bahwa budaya makan dengan tangan tidak berpengaruh terhadap penyebaran Covid-19 di Kota Bandung. Kesimpulan ini dapat didapatkan dari frekuensi makan dengan tangan yang sama dari penduduk Kota Bandung yang pernah dan tidak pernah terjangkit Covid-19. Berarti, faktor kebiasaan lain seperti kebiasaan memakai masker, kebiasaan berkerumun selama pandemi, dan kebiasaan mencuci tangan lah yang mempengaruhi penyebaran Covid-19.

Faktor-faktor seperti jumlah responden yang kurang banyak dan juga singkatnya waktu pengerjaan mempengaruhi keakuratan penelitian ini. Selain itu, pencarian literatur berupa jurnal tentang budaya mencuci tangan juga sulit dilakukan sehingga menghambar penelitian ini dan menyebabkan pembahasan penelitian dari segi budaya sulit dilakukan. Kami berharap penelitian kami dapat dijadikan referensi untuk penelitian berikutnya dan metode yang kami lakukan dapat disempurnakan.

Puji dan syukur kami panjatkan kepada Tuhan yang Maha Kuasa atas berkat dan rahmat dan hidayah-Nya kami dapat menyelesaikan jurnal kami yang berjudul "Pengaruh Budaya Makan dengan Tangan terhadap Penyebaran Covid-19 di Kota Bandung" selesai pada waktunya. Pada kesempatan ini, kami hendak menyampaikan terima kasih kepada semua pihak yang telah memberikan dukungan moril maupun materil sehingga jurnal ini dapat tersusun hingga selesai. Kami menyadari, begitu banyak bantuan yang diberikan dalam pembuatan jurnal ini. Tanpa bantuan dari berbagai pihak, hasil makalah ini tidak akan tercapai. Karena itu, ucapan terima kasih yang sebesar-besarnya disampaikan kepada Tuhan yang Maha Esa yang telah memberikan kami kesehatan dan kesempatan untuk dapat menyelesaikan jurnal ini, Bapak Harry Nuriman, M.Si. selaku dosen mata kuliah Pancasila dan Kewarganegaraan, dan semua orang yang berkontribusi dalam pembuatan jurnal ini.

\section{DAFTAR PUSTAKA}

Armiani, S., Fajri, S. R., Sukri, A., \& Pidiawati, B. Y. (2020). Pelatihan pembuatan masker sebagai upaya antisipasi penyebaran covid-19 di Desa Anyar Kabupaten Lombok Utara. Jurnal Pengabdian UNDIKMA, 1(1).

Aulia, F. (2021, October 1). Evaluasi 19 Bulan Kinerja Covid-19 di Indonesia, Antara Konspirasi dan Realita. MUDA News. Retrieved November 23, 2021, from 
https://mudanews.com/opini/2021/10/01/evaluasi-19-bulan-kinerja-covid-19-diindonesia-antara-konspirasi-dan-realita/

Gunawan, H., Septiana, Y., \& Gunadhi, E. (2020). Rancang Bangun Media Pembelajaran Pengenalan Ragam Budaya Indonesia Berbasis Android. Jurnal Algoritma, 17(1), 82-90. GÜNER, H. R., Hasanoğlu, İ., \& Aktaş, F. (2020). COVID-19: Prevention and control measures in community. Turkish Journal of medical sciences, 50(SI-1), 571-577.

Lotfi, M., Hamblin, M. R., \& Rezaei, N. (2020). COVID-19: Transmission, prevention, and potential therapeutic opportunities. Clinica chimica acta, 508, 254-266.

Nurgiansah, T. H. (2020a). Build An Attitude of Nationalism Students At SDN 7 Kadipaten With The Method of Discusion In The Subject PPKn. Jurnal Serunai Pendidikan Pancasila Dan Kewarganegaraan STKIP Budi Daya Binjai, 9(1), 1-11.

Nurgiansah, T. H. (2020b). Fenomena Prostitusi Online Di Kota Yogyakarta Dalam Persfektif Nilai Kemanusiaan Yang Adil Dan Beradab. Jurnal Kewarganegaraan, 17(1), 27-34. https://doi.org/10.24114/jk.v17i1.14208

Nurgiansah, T. H. (2020c). Pelatihan Penulisan Artikel Ilmiah Bagi Mahasiswa PPKn Universitas PGRI Yogyakarta. JNPM: Jurnal Nasional Pengabdian Masyarakat, 1(1), 16-23.

Nurgiansah, T. H. (2021a). Partisipasi Politik Masyarakat Sleman di Masa Pandemi Covid-19 dalam Konteks Pendidikan Kewarganegaraan. Jurnal Civic Hukum, 6(1), 1-9.

Nurgiansah, T. H. (2021b). Pelatihan Penelitian Tindakan Kelas Bagi Guru Pendidikan Kewarganegaraan Di Sekolah Menengah Atas Se-Kabupaten Bantul. BERNAS: Jurnal Pengabdian Kepada Masyarakat, 2(1), 28-33. https://doi.org/10.31949/jb.v2i1.566

Nurgiansah, T. H. (2021c). Pemanfaatan E-Learning Dalam Pembelajaran Pendidikan Kewarganegaraan. JINTECH: Journal of Information Technology, 2(2), 138-146.

Nurgiansah, T. H. (2021d). Pendidikan Pancasila Sebagai Upaya Membentuk Karakter Jujur. Jurnal Pendidikan Kewarganegaraan Undiksha, 9(1), 33-41.

Nurgiansah, T. H. (2021e). Petuah Pendidikan Kewarganegaraan Dalam Kontestasi Politik. AoEJ: Academy of Education Journal, 12(1), 39-47.

Nurgiansah, T. H. (2021f). The Role of Citizenship Education in Building Bantul Community Political Participation in The Pandemic Covid 19. Prosiding Seminar Nasional Pendidikan Dan Kewirausahaan, 4(1), 1-4.

Pradhan, D., Biswasroy, P., Naik, P. K., Ghosh, G., \& Rath, G. (2020). A review of current interventions for COVID-19 prevention. Archives of medical research, 51(5), 363-374.

Rachman, F., Ryan, T., Kabatiah, M., Batubara, A., Pratama, F. F., \& Nurgiansah, T. H. (2021). Pelaksanaan Kurikulum PPKn pada Kondisi Khusus Pandemi Covid-19. Jurnal Basicedu, 5(6), 5682-5691.

Riedel S., et al. (2019). Medical Microbiology. 28th ed. New York: McGrawHill Education/Medical.

Suryani, H., Irmayanti, I., \& Suryana, S. (2020, November). Pemanfaatan Perca Kain Dalam Mencegah Virus Corona. In Seminar Nasional Pengabdian Kepada Masyarakat.

Wasaraka, Y. N. (2021). KEBIASAAN MAKAN DAN KEBIASAAN CUCI TANGAN MASYARAKAT SELAMA MASA PANDEMI COVID 19 DI KOTA JAYAPURA. Healthy Papua-Jurnal keperawatan dan Kesehatan, 4(1), 173-182.

World Health Organization. (2020). Transmisi SARS-CoV-2: implikasi terhadap kewaspadaan pencegahan infeksi. Pernyataan Keilmuan, 1-10.

Yanuarita, H. A., \& Haryati, S. (2021). Pengaruh Covid-19 Terhadap Kondisi Sosial Budaya Di Kota Malang Dan Konsep Strategis Dalam Penanganannya. Jurnal Ilmiah Widya Sosiopolitika, 2(2), 58. 